\title{
Хасанов Н.Б. \\ Формирование навыков и умений профессионального речевого общения у студентов технических вузов
}

Кыргызский государственный университет строительства, транспорта и архитектуры имени Н. Исанова (Кыргызская Республика, Бишкек)

doi: 10.18411/lj-07-2021-158

\section{Аннотация}

В связи с процессами глобализации и интеграции Кыргызской Республики в мировое пространство, проводимыми экономическими реформами и активным сотрудничеством нашего государства с зарубежными странами возрастает необходимость подготовки специалистов, профессионализм которых напрямую зависит от уровня и качества коммуникативной компетенции, готовых вступать в профессионально-деловое общение с представителями других культур. Вопросы формирования речевой компетенции были всегда в поле зрения лингводидактиков, методистов, преподавателей. Многие аспекты этой проблемы были рассмотрены, как кыргызскими учеными, так и зарубежными. Целью исследования является создание научно обоснованной методики формирования речевой компетенции студентов в процессе обучения русскому языку в техническом вузе. В данной статье представлено обоснование необходимости практического решения объективно назревшей проблемы формирования речевой компетентности обучающихся в вузе. В условиях усложнения коммуникационной профессиональной среды, на фоне глобальной информатизации и компьютеризации образования в целом, обязательным преимуществом профессионалов являются умения и навыки эффективного речевого общения. В статье представлены результаты исследования, позволившие выделить типичные недостатки речи будущих специалистов инженерного профиля.

Обобщение полученных результатов исследования и выводы автора статьи раскрывают отдельные аспекты многогранной проблемы формирования речевой компетентности обучающихся и указывают на необходимость ее дальнейшей разработки на основе интеграции практического опыта и теоретического знания из различных областей наук.

Ключевые слова: речевая компетенция, компетенция, практический курс русского языка, технический вуз, навыки и умения, компетентность, профессиональная компетентность, общение, профессиональная направленность.

\section{Abstract}

In connection with the processes of globalization and integration of the Kyrgyz Republic into the world affairs, the ongoing economic reforms and active cooperation of our state with foreign countries, there is an increasing need for training of specialists, whose professionalism directly depends on the level and quality of communicative competence, ready to enter into professional and business communication with representatives of other cultures. Questions of the formation of speech competence have always been in the field of vision of linguodidacticians, methodologists, and teachers. Many aspects of this problem were considered by both Kyrgyz and foreign scientists. The aim of the study is to create a scientifically grounded methodology for the formation of students' speech competence in the process of teaching Russian language at technical universities. This article presents the substantiation of the need for a practical solution to the objectively urgent problem of the formation of speech competence of students at a university. In the context of the increasing complexity of the communicative professional environment, against the background of global informatization and computerization of education in general, the skills and abilities of 
effective verbal communication are an obligatory advantage of professionals. The article presents the results of the study, which made it possible to highlight the typical shortcomings of the speech of future engineering specialists. The generalization of the results of the study and the conclusions of the author of the article reveal certain aspects of the multifaceted problem of the formation of speech competence of students and indicate the need for its further development based on the integration of practical experience and theoretical knowledge from various fields of science.

Keywords: speech competence, competence, practical course of the Russian language, technical university, skills and abilities, competence, professional competence, communication, professional orientation.

В профессиональной подготовке студентов инженерного профиля большую роль играет практический курс русского языка. Эта дисциплина требует к себе пристального внимания как выполняющая важнейший социальный заказ - обучение русскому языку как средству межнационального общения. По мнению современных исследователей, «речевая компетентность, с одной стороны, является органической частью коммуникативной компетентности образованного человека, а с другой - значимым профессиональным качеством педагога, входящим в состав его профессиональной компетентности [3].

Практический курс русского языка в техническом вузе призван совершенствовать навыки и умения устной и письменной речи студентов и, таким образом, готовить их к восприятию последующих учебных спецдисциплин. Перед курсом стоит целый ряд других сложных задач. И одна из них - обучение студентов навыкам и умениям профессионального общения.

Для решения этой задачи важно выявить, в какой мере работа в названном направлении определена квалификационной характеристикой, программой данного курса, имеющимися учебными пособиями, методическими рекомендациями.

Надо сказать, что квалификационная характеристика инженера-строителя раскрывает лишь общие требования к подготовке инженера, устанавливает объем общих и специальных знаний, навыков и умений, которыми определяется и обеспечивается профессия инженера-строителя. Но она не содержит указаний, какие именно профессиональные навыки и умения могут быть сформированы на материале отдельных дисциплин.

Анализ соответствующей методической литературы показывает, что программы практического курса русского языка составлены с учетом профессиональной направленности обучения. Однако в этих программах представлено лишь общее понятие профессиональной направленности обучения и даются такие формы ее выражения, как: а) терминология; б) ситуации; в) тексты.

Профессиональное же речевое общение как форма профессиональной направленности обучения своего отражения в указанных документах не находит.

Определен программами и минимум требований к навыкам и умениям, которыми должен овладеть студент в процессе обучения. Но профессиональные навыки и умения, в том числе навыки и умения профессионального речевого общения, не выделяются.

Таким образом, принцип профессиональной направленности обучения авторами программ учитывается, но раскрывается не полной мере.

В методических рекомендациях являющихся своеобразным дополнением к программе практического курса русского языка также рассматривается ряд аспектов осуществления профессиональной направленности обучения. Студентам предлагается систематически выполнять задания, которые способствуют приобретению профессиональных умений и навыков. Определяются в этих рекомендациях некоторые навыки и умения, необходимые студентам в их будущей профессиональной 
деятельности (например: уметь составлять резюме, самостоятельно подбирать материал из разнообразных источников).

Таким образом, принцип профессиональной направленности представлен достаточно широко. Но тут, однако, выявлены далеко не все профессиональные умения и навыки, которые должны быть сформированы у студентов в процессе обучения, хотя жанр методических рекомендаций позволяет это сделать.

Вместе с тем представляется, что осуществление профессиональной направленности обучения в практическом курсе русского языка не может сводиться только к сообщению лексики по специальности и к использованию технической терминологии, учебных текстов, близких по тематике и содержанию к будущей специальности. Содержание обучения, определяемое учебным планом, дает основание для выделения и других форм организации профессиональной подготовки, в том числе - по формированию профессионально необходимых навыков и умений. И прежде всего - навыков и умений профессионального речевого общения.

По результатам научно-методической литературы видно, что к этому вопросу обращались такие ученые, как Н.А. Ахметова [2], 3.И. Гирич [4], К.Д. Добаев [5], Г.А. Касаболотова [6], Д.Д. Куттубаева, [7], Н.Б. Хасанов [8; 9], Г.М. Ходжиматова [10].

С целью успешнего осуществления профессиональной подготовки будущих инженеров в практическом курсе русского языка необходимо установить перечень навыков и умений профессионального речевого общения, разработать систему заданий по их формированию, способы проверки эффективности разработанной системы.

В рамках этой дисциплины студентов учим составлять аннотации к статьям, текстам; отличать научный стиль от других стилей речи; составлять планы различного характера (вопросный, назывной, тезисный); работать с текстами по специальности, а также научной литературой; составлять резюме, рефераты и доклады на разные темы; учим составлять введение к своим выступлениям на занятиях, написать отзывы и рецензии к статьям, текстам из периодики; готовить презентации своих выступлений, докладов; участвовать в дискуссиях, конференциях; составлять тезисы докладов, а также правильно пользоваться умениями и навыками устной и письменной речи.

Основу программного материала или силлабуса составляют тексты научного характера по спецдисциплинам. Ниже для образца приводим темы занятий по теме «Из истории науки. Наука в жизни общества», проводимого нами в Кыргызском государственном университете строительства, транспорта и архитектуры имени Н. Исанова: например, для студентов из института новых информационных технологий при проведении темы "Наука в жизни общества “ студентам можно предложили такие темы, как: «Ученые прошлого и их открытия», «Роль науки в современном обществе», «Из истории компьютера», «Что мы знаем об интернете», «Откуда берутся научнофантастические идеи?», «Научно-техническая революция», «Нано технологии», «Вклад ученых Кыргызстана и КГУСТА в науку. Ученые современности», «Открытия в области моей специальности», «Наука: вчера, сегодня, завтра» и другие [5].

Для студентов направлений подготовки 670300 - Технология транспортных процессов, профиль: «Организация и безопасность движения», 670300 - Технология транспортных процессов, профиль: «Организация перевозок и управление на транспорте”, 670300 - «Технология транспортных процессов», профиль: «Таможенное дело на транспорте» предложили такие темы: “Классификация автомобилей”, "Классификация и назначение двигателей внутреннего сгорания", “Основные показатели ДВС и его общее устройство", “Общее устройство автомобиля. Шасси. Трансмиссия", “Общее устройство автомобиля. Шасси. Ходовая часть”, “Общее устройство автомобиля. Шасси. Механизмы управления” и другие.

Для студентов 580100 - «Экономика, профиль “Менеджмент организации", 580100 - «Экономика, профиль: «Бухгалтерский учет, анализ и аудит (в строительстве)» при проведении темы: “Моя специальность” предлагаем следующие темы: “Экономика 
как наука”, “Микроэкономика", “Макроэкономика как раздел экономической теории”, "Макроэкономика и товарное производство", "Понятие и структура рынка", "Рыночная система экономики”, “Менеджмент, его цели, задачи, функции” и другие [4].

Речевые темы строятся на материале грамматических: лексика научного стиля речи; употребление научной терминологии; общенаучные, узкоспециальные термины; описание, повествование, рассуждение; глаголы и отглагольные существительные; синтаксис сложного предложения; сложносочиненные предложения; цитаты.

Темы рефератов, с которыми выступают студенты, должны быть тесно взаимосвязаны с будущей специальностью студентов, а также уроки-конференции и их проведение положительно влияют на информативность и полезность в обучении языкам.

При этом следует иметь в виду, что далеко не все профессиональные навыки и умения должны формироваться в практическом курсе русского языка. Исходя из учета принципа межпредметных связей практического курса русского языка с курсами кыргызского, иностранных языков и методики его преподавания представляется целесообразным выделить две группы профессиональных навыков и умений:

a) навыки и умения профессионального речевого общения, формирование которых происходит при учебном речевом общении студентов с преподавателем. Специфика практического курса русского языка, его близость с другими языковыми курсами, а также профессиональная адекватность речи преподавателя поможет также в развитии профессиональных навыков и умений студентов.

б) профессиональные навыки и умения, формирование которых получает логическое продолжение в изучении спецдисциплин. В этом случае речь идет о совершенствовании знаний по другим разделам русской грамматики, формировании навыков и умений практической методики, самообразования и самоподготовки студентов.

Следует отметить, что уровень сформированности речевых навыков и умений у студентов неодинаков. Одни студенты, в плане развития речи, более подготовлены к своей будущей профессии, у других речевые навыки и умения сформированы недостаточно. Но и у тех, и у других чаще встречаются речевые ошибки.

На наш взгляд, при изучении данного курса у студентов должны быть сформированы такие навыки и умения профессионального речевого общения:

1) Умение слушать и замечать речевые ошибки своих однокурсников; своевременно корректировать их ошибки;

2) Умение контролировать устную свою речь;

3) Умение четко, ясно, логично изложить предложенный материал текста, задания;

4) Навыки и умения эмоционально-экспрессивного речевого поведения на занятии; эмоциональность, выразительность, четкость правильность, чистота говорения на русском языке;

5) Умение речевого воспитания: воспитывать культуру русской речи студентов.

Таким образом, в настоящее время основными целями дисциплины по изучению русского языка в техническом вузе выступают:

- ознакомление с языком, введение в его азы, пояснения специфических индивидуальностей и различных речевых конструктов, пояснение главных отличий между языковой и речевой формами;

- углубление знаний о языке и речи, разделение между монологом и диалогом, введение в основы правописания;

- введение в общепринятую коммуникацию в деловом контексте, в том числе рабочие собрания, а также разговоры по телефонной связи, беседы, с их структурой; 
- анализ структуры построения речевого акта, то есть социальных ролей коммуникантов, их общественный опыт, контекст, а также формирование коммуникативных компетенций;

- овладение техникой речи, знание норм русского литературного языка;

- овладеть навыками выступлений перед камерой, перед микрофоном, использование в своей будущей работе технических средств, компьютерных систем, электронной почты, переговорных устройств.

Таков примерный минимум навыков и умений профессионального речевого общения, которые могут быть сформированы в процессе обучения студентов на занятиях практического курса русского языка. При этом следует отметить, что четко разграничить профессиональные функции речи у будущего инженера невозможно.

Следовательно, формирование речевой компетентности студентов в условиях усложнения информационной и коммуникационной профессиональной среды первостепенная задача, которая должна решаться еще на этапе их учебнопрофессиональной подготовки в вузе [1].

Обобщение полученных результатов исследования и выводы автора статьи раскрывают отдельные аспекты многогранной проблемы формирования речевой компетентности обучающихся и указывают на необходимость ее дальнейшей разработки на основе интеграции практического опыта и теоретического знания из различных областей наук.

$$
* * *
$$

1. Артемьева Г.Н. Формирование речевой компетентности будущих специалистов в области образования на этапе профессиональной подготовки в вузе // Мир науки. Педагогика и психология, 2020 №1, https://mir-nauki.com/PDF/76PDMN120.pdf (доступ свободный)

2. Ахметова Н.А., Таштанкулова Ж.Ж. Использование метода проектов при обучении устному общению на русском языке как неродному // Педагогика и психология: актуальные вопросы теории и практики. 2016. № 3 (8). С. 44-47.

3. Гирич 3. И. Особенности конструирования тестов, ориентированных на тюркоязычную аудиторию // Вісник Дніпропетровського університету імені Альфреда Нобеля. Серія «Педагогіка i психологія». Педагогічні науки, 2014. С. 102-107.

4. Добаев К.Д. Система высшего образования Кыргызстана: переход на двухуровневую систему // Известия Кыргызской академии образования. Бишкек, 2011. № 4. С. 49-52.

5. Касаболотова Г.А. Обучение профессионально ориентированному чтению на русском языке студентов-бакалавров национальных групп языковых факультетов : авторефер. дис. ...канд. пед. наук : 13.00.02. Бишкек, 2017. 23 с.

6. Куттубаева Д.Д. Назначение и объем лексического минимума в обучении лексике студентов национальных групп неязыковых факультетов // Вестник КГУ им. И. Арабаева. Бишкек, 2012. № 1. C. $126-128$.

7. Х Хасанов Н.Б. Практический курс русского языка /учеб. метод. пособие. Бишкек., 2016. - 260 с.

8. Хасанов Н.Б. Изучение темы «Моя специальность» на занятиях русского языка в техническом вузе // Научный мир Казахстана/ - Тараз, 2012. - № 2. - С. 224-228.

9. Ходжиматова Г.М. Научные основы обучения терминологической лексике русского языка в неязыковом вузе : дис. ... д-ра пед. наук : 13.00.02. Душанбе, 2011. 320 с.

\section{Эхаева P.М. \\ Инновационные формы проведения родительских собраний в образовательных организациях}

ФГБОУ ВО «Чеченский государственный университет»

(Россия, Грозныгй)

doi: 10.18411/lj-07-2021-159

\section{Аннотация}

Традиционная форма контактов школы и родителей - родительские собрания. Существует тенденция: снижение посещаемости родительских собраний по мере 